\title{
Prevalence and risk factors for HBV, HCV and HDV infections among injecting drug users from Rio de Janeiro, Brazil
}

M.L.A. O liveira1 , F.I. Bastos², P.R. Telles ${ }^{3}$, C.F.T. Yoshida ${ }^{1}$, H.G. Schatzmayr ${ }^{1}$, U. Paetzold ${ }^{4}$, G. Pauli ${ }^{4}$ and E. Schreier ${ }^{4}$

\section{Correspondence \\ M.L.A. Oliveira \\ Laboratório de Hepatites Virais \\ Departamento de Virologia \\ Instituto O swaldo Cruz, FIO CRUZ \\ Av. Brasil, 4365 \\ 21040-360 Rio de Janeiro, RJ \\ Brasil \\ Fax: + 55-21-270-6397 \\ E-mail: lou@gene.dbbm.fiocruz.br \\ M.L.A. O liveira was supported by the Robert Koch Institute, Berlin, Germany. F.I. Bastos, C.F.T. Yoshida and P.R. Telles were supported by CNPq and FAPERJ.}

Received August 24, 1998

Accepted June 1, 1999

\author{
'Laboratório de Hepatites Virais, Departamento de Virologia, and \\ ${ }^{2}$ Departamento de Informações para a Saúde, Centro de Informação em Ciência e \\ Tecnologia, Instituto O swaldo Cruz, FIO CRUZ, Rio de Janeiro, RJ, Brasil \\ ${ }^{3}$ Núcleo de Estudos e Pesquisas em Atenção ao U so de Drogas (NEPAD), \\ Universidade Estadual do Rio de Janeiro, Rio de Janeiro, RJ, Brasil \\ ${ }^{4}$ Department of Virology, Robert Koch Institute, Berlin, Germany
}

\section{Abstract}

Viral hepatitis constitutes a major health issue, with high prevalence among injecting drug users (IDUs). The present study assessed the prevalence and risk determinants for hepatitis $\mathrm{B}, \mathrm{C}$ and $\mathrm{D}$ viruses (HBV, HCV and HDV) infections among 102 IDUs from Rio de Janeiro, Brazil. Serological markers and HCV-RNA were detected by enzyme immunoassay and nested PCR, respectively. HCV genotyping was determined by restriction fragment length polymorphism analysis (RFLP). HBsAg, anti-HBc and anti-HBs were found in 7.8, 55.8 and $24.7 \%$ of IDUs, respectively. In the final logistic regression, HBV infection was independently associated with male homosexual intercourse within the last 5 years (odds ratio (OR) 3.1; 95\% confidence interval (CI) 1.1-8.8). No subject presented anti-delta (anti-HD). Anti$\mathrm{HCV}$ was detected in $69.6 \%$ of subjects, and was found to be independently associated with needle sharing in the last 6 months (OR 3.4; 95\% CI 1.3-9.2) and with longer duration of $i v$ drug use (OR 3.1; 95\% CI 1.1-8.7). These data demonstrate that this population is at high risk for both HBV and HCV infection. Among IDUs from Rio de Janeiro, unprotected sexual intercourse seems to be more closely associated with $\mathrm{HBV}$ infection, whereas $\mathrm{HCV}$ is positively correlated with high risk injecting behavior. Comprehensive public health interventions targeting this population and their sexual partners must be encouraged.

\section{Introduction}

Viral hepatitis constitutes a major health issue and can be caused by different etiologic agents (1). These infections are spread worldwide, although with varying prevalence in different regions. It is estimated that there

\author{
Key words \\ - HBV \\ - HDV \\ - HCV \\ - HCV genotypes \\ - IDU
}


mately 20 to $30 \%$ of these patients are at risk for developing cirrhosis (4).

Blood-borne hepatitis can become a chronic infection at proportions which vary depending on the causative agent. Among adults with HBV infection, $5-10 \%$ of cases can become chronic and a higher frequency is observed in HDV (70-90\%) and HCV (90\%) superinfection (4-6). Liver cirrhosis and hepatocellular carcinoma constitute major late complications of viral hepatitis $(3,7)$. HBV and HDV are associated with fulminant hepatitis in about $1-2 \%$ and $2-20 \%$ of acute cases, respectively, whereas HCV is rarely associated with this complication (4-6).

Injecting drug users (IDUs) constitute a group of frequent exposure to many viral infections, since they usually engage in high risk sexual and injecting behavior (8). Furthermore, these subjects play a role as a reservoir and source of viral transmission in the inter- and extra-exposure categories. The prevalence of blood-borne hepatitis is usually higher among IDU than in other comparable non-IDU population strata (9). Epidemiological data indicate that IDUs represent the largest risk group for $\mathrm{HCV}$ infection (10).

The aim of the present study was to assess the frequency of HBV, HCV and HDV infections and their respective risk factors among IDUs from Rio de Janeiro, Brazil.

\section{Subjects and Methods}

\section{IDU population}

The sample analyzed here was part of an epidemiological multicenter project about human immunodeficiency virus (HIV) risks among IDUs in five Brazilian cities (Projeto Brasil). A survey was carried out on 102 volunteers selected at drug use treatment centers and from the "drug scene" ("streets") of the city. The injecting users recruited from the "drug scene" were enrolled from different sources, based on previous experience of the research team in a former multicity study (11). Many different places were assessed such as public places, nightclubs and bars, scattered through various neighborhoods of the city of Rio de Janeiro. The technique used was chain (or successive) referral - usually called snowball sampling recently shown to be reliable as a recruiting strategy in a case-control study carried out in Rio de Janeiro (12). Recruiters were specially trained for this task and all efforts were made to guarantee the privacy of the interviewees.

IDUs recruited from drug use treatment centers came basically from three reference centers in Rio de Janeiro, located respectively in the northern and western regions of the city, and in a neighboring municipality, the latter enrolling basically patients from the city and its surroundings ("Greater Rio"). According to ethical guidelines, formal consent was obtained from each individual, who was interviewed using a standardized questionnaire including questions about sociodemographic status, pattern of $i v$ drug use and sexual behavior. All subjects were tested for the presence of anti-HBc, $\mathrm{HBsAg}$, antidelta (anti-HD) and anti-HCV. Because of insufficient blood sample, only 89 sera could be tested for the presence of anti-HBs. Except for 3 samples, detection of HCV-RNA was performed in all anti-HCV-positive subjects $(\mathrm{N}=68)$. For HCV genotyping, sera from 39 IDUs were submitted to restriction fragment length polymorphism analysis (RFLP).

\section{Characterization of HBV, HDV and HCV infections}

Plasma samples were tested for the presence of HBV serological markers by enzyme immunoassays. Tests for $\mathrm{HBsAg}$, anti-HBc and anti-HBs were carried out using the Hepanostika HBsAg Uniform II kit, Hepanostika anti-HBc Uniform kit and 
Hepanostika anti-HBs kit (Organon Teknika, Boxtel, Holland), respectively. HBV infection was defined by the presence of anti-HBc with or without other HBV markers. AntiHD were tested by a commercial EIA kit (Abbott Laboratories, Diagnostic Division, Chicago, IL, USA). Anti-HCV testing was performed using a third-generation recombinant assay (Abbott HCV EIA 3.0, Abbott Laboratories).

For the detection of HCV-RNA, viral RNA was extracted from $200 \mu$ l of plasma using the QIAmp Blood and QIAmp Tissue kit (QIAGEN GmbH, Hilden, Germany). The extracted RNA was eluted in $100 \mu 1$ of DEPCtreated water. Reverse transcription was carried out with $2.5 \mu 1$ of RNA in a final volume of $10 \mu \mathrm{l}$. The mixture was incubated at $42^{\circ} \mathrm{C}$ for $60 \mathrm{~min}$ and then at $95^{\circ} \mathrm{C}$ for $5 \mathrm{~min}$. In the first and second PCR rounds for HCV 5 ' $\mathrm{NCR}$ detection, we used $2.5 \mu \mathrm{l}$ of reverse transcription (RT) and first PCR product, respectively, in a final volume of $25 \mu \mathrm{l}$. The cycling protocol consisted of 35 cycles of $94^{\circ} \mathrm{C}$ for $1 \mathrm{~min}, 54^{\circ} \mathrm{C}$ for $1 \mathrm{~min}$ and $72^{\circ} \mathrm{C}$ for $2 \mathrm{~min}$, followed by a final cycle of $72^{\circ} \mathrm{C}$ for $5 \mathrm{~min}$. The sequences of the outer and inner primers were $1 \mathrm{~b}$ (5'GGTGCACGGTCTAC GAGACC3') and 2a (5'GGCGACACTCC RCGAT3'), 56 (5'CGCAAGCACCCTAT CAGGGCAGT3') and 4 (5'GAGGAACTA CTGTCTTCACGCAGAA3'), respectively. The product of the second round of PCR, composed of 260 base pairs, was subjected to electrophoresis using a $2 \%$ agarose gel in TBE buffer and visualized by ethidium bromide staining under ultraviolet light. HCV genotyping by RFLP was performed as described elsewhere (13) and genotypes were determined according to Simmonds' classification (14).

\section{Statistical analysis}

A database consisting of socio-demographic characteristics, pattern of $i v$ drug use, sexual behavior and test results was set up using Epiinfo version 6.2 (Centers for Diseases Control and Prevention, Atlanta, GA, USA). Statistical analysis and data merging were performed using the SPSS 8.0 statistical package for IBM-PC. Serological markers and HCV genotypes were correlated with the data described above. Contingency table analysis (chi-square and Fisher exact test, Yates corrected) and $t$-test for means were employed. Results were regarded as significant when $P<0.05$. To further assess the independent role of the different variables associated with $\mathrm{HBV}$ and $\mathrm{HCV}$ infection, stepwise multiple logistic regressions with backward elimination were carried out.

\section{Results}

\section{Demographic characteristics, pattern of iv drug use and sexual behavior}

Of the 102 IDUs investigated, 88 were males $(85.4 \%), 15$ were females $(14.6 \%)$, and the mean age was $33.7 \pm 7.6$ years. The majority was employed (44.7\%) or had a temporary job $(45.6 \%)$, while $9.7 \%$ had mainly illegal sources of income like drug dealing, prostitution or others. About 54\% of the IDUs had lower than high school education. Most individuals reported a history of former imprisonment (50\% with 1 to 4 occurrences and $23.5 \%$ with more than 5 occurrences). Among the subjects, only 4 (5\%) reported sharing injection equipment while in prison. Respectively 53.5 and $46.8 \%$ of the individuals lived in middle class and low-income districts.

The most frequently injected drug was cocaine ( $92.2 \%)$, followed by heroin (11.6\%), the latter generally injected during trips abroad. Other drugs such as injectable or non-injectable amphetamines, solvents, tranquilizers and cannabis were also consumed. The mean age at first injection was 19.6 \pm 5.2 years, and the mean duration of $i v$ drug use was $13.9 \pm 8.8$ years. With respect to the 
frequency of injection, $24.7 \%$ of subjects injected 1 to 3 times a month, 35.5\%, 1 to 3 times a week and $39.8 \%$, more than 3 times a week. We found a very high frequency of needle sharing (64.3\%) in the last six months prior to the interview (Table 1).

Individuals presented high levels of sexual risk behaviors. Despite sexual orientation (hetero- or homosexual) or the nature of the partnership (principal or occasional partners, or clients), the vast majority of subjects reported irregular or no use of condoms (over $70 \%$ for all partnerships under analysis) (Table 1).

\section{HBV, HDV and HCV infections}

Results for HBV serological markers (HBsAg, anti-HBc and anti-HBs), anti-HCV, HCV-RNA and HCV genotypes and antiHD are presented in Table 2 and associations between socio-demographic characteristics, parenteral and sexual risk behaviors and infection rates are shown in Table 3.

HBV infection was significantly associated with a history of imprisonment $(\mathrm{P}<0.04)$ and male homosexual intercourse within the last 5 years $(\mathrm{P}<0.04)$ (Table 3$)$. Conversely, no association was found between HBV in-

Table 1 - Injecting and sexual risk behaviors among IDUs from Rio de J aneiro, Brazil (1994-1996).

*Among 56 interviewees who reported homosexual intercourse in the last 6 months before the interview.

Risk behaviors

$\%(\mathrm{~N}=102)$

Injecting behavior

Frequency of injection in the last 6 months

1 to 3 times a month

24.7

1 to 3 times a week

35.5

$>3$ times a week

39.8

Frequency of needle sharing in the last 6 months

64.3

Sexual intercourse in the last 6 months with irregular/no use of condoms Heterosexual intercourse with a principal partner Heterosexual intercourse with an occasional partner Heterosexual intercourse with a client

77.4

Male homosexual intercourse* fection and parenteral exposure parameters, suggesting that HBV was more efficiently transmitted by the sexual route. Associations between the response variable and the variables shown to be significantly associated with it by univariate analysis were controlled for potential confounders and assessed by multiple logistic regression procedures. The final multiple logistic regression model (chi-square model $=4.5 ; \mathrm{P}=0.03$ ) identified "male homosexual intercourse within the last 5 years" as the exclusive independent risk factor (odds ratio (OR) 3.1; 95\% confidence interval (CI) 1.1-8.8) for HBV infection in this sample.

$\mathrm{HCV}$ infection was significantly associated with male gender $(\mathrm{P}<0.04)$, age $(\mathrm{P}<0.04)$, history of imprisonment $(\mathrm{P}<0.006)$, age at first injection $(\mathrm{P}<0.03)$, longer duration of $i v$ drug use $(\mathrm{P}<0.005)$ and needle sharing $(\mathrm{P}<0.003)$ (Table 3). The final multiple logistic regression model (chi-square model $=$ 13.11; $\mathrm{P}=0.002)$ identified as independent risk factors for $\mathrm{HCV}$ infection: longer "duration of $i v$ drug use" (OR 3.1; 95\% CI 1.1-8.7) and "needle sharing in the last six months" (OR 3.4; 95\%CI 1.3-9.2). Although HCV genotype 1 was the most prevalent $(56.4 \%$, $22 / 39$ ), a relatively high frequency of $\mathrm{HCV}$ genotype 3 infection was observed (35.9\%, 14/39), when compared with other populations from Rio de Janeiro previously assessed (15). Genotype 2 was found in only 3 subjects $(7.7 \%)$, a fact that precludes further evaluation.

The variables associated with HCV genotype 3 infection (as compared to HCV genotype 1 infection) were younger age at first injection $(\mathrm{P}<0.03)$, a longer duration of $i v$ drug use $(\mathrm{P}<0.05)$ and a higher frequency of injection $(\mathrm{P}<0.04)$ (Table 3). Although not statistically significant (probably due to the small size of the subsample), a tendency toward higher levels of HCV genotype 3 infection among individuals with a history of imprisonment and male homosexual intercourse was also observed. 
For evaluation of multiple infection, we considered anti-HBc and anti-HCV as markers of $\mathrm{HBV}$ and $\mathrm{HCV}$ exposure, respectively. We found a $38.2 \%$ rate $(39 / 102)$ of $\mathrm{HBV} / \mathrm{HCV}$ co-infection.

\section{Discussion}

The present study shows a high prevalence of blood-borne viral hepatitis among IDUs from Rio de Janeiro. IDUs are more exposed to many viral agents by the sexual and/or parenteral routes, as shown by the high rate of needle sharing (64.3\%) and the low rate of condom use. Additionally, secondary risks such as sharing injection paraphernalia other than needles and syringes should be considered (16).

Rio de Janeiro is a region of low endemicity for $\mathrm{HBV}$ infection $(<2 \% \mathrm{HBsAg}$ prevalence) (17). The frequency of HBsAg found in this study $(7.8 \%)$ is comparable with that observed in areas of high endemicity, with more than $8 \%$ of HBsAg prevalence, and agrees with results from other studies of IDUs in Santos, SP, Brazil (18), and in other countries (9). HBV infection was significantly associated with male ho- mosexual intercourse, but no association with parenteral exposure variables was found. This profile suggests that unsafe sex represents the major risk determinant for HBV transmission among IDUs in Rio de Janeiro. The history of imprisonment did not remain in the final logistic regression model, and seems to be a confounder.

In our study, anti-HCV was detected in

\begin{tabular}{|c|c|}
\hline Markers & $\%(+/ N)$ \\
\hline \multicolumn{2}{|l|}{ HBV } \\
\hline HBsAg & $7.8(8 / 102)$ \\
\hline Anti-HBc & $55.8(57 / 102)$ \\
\hline Anti-HBs & $24.7(22 / 89)$ \\
\hline \multicolumn{2}{|l|}{$\mathrm{HCV}$} \\
\hline Anti-HCV & $69.6(71 / 102)$ \\
\hline HCV-RNA & $70.6(48 / 68)$ \\
\hline HCV genotype 1 & $56.4(22 / 39)$ \\
\hline HCV genotype 2 & $7.7(3 / 39)$ \\
\hline HCV genotype 3 & $35.9(14 / 39)$ \\
\hline \multicolumn{2}{|l|}{ HDV } \\
\hline Anti-delta & $0.0(0 / 102)$ \\
\hline
\end{tabular}

Table 3 - Main associations between socio-demographic characteristics, parenteral and sexual risk behaviors and infection rates for HBV and HCVb infections and HCV genotypes among IDUs from Rio de J aneiro, Brazil (1994-1996).

aHBV infection was defined by the presence of anti-HBc with or without any other HBV serological marker. bHCV infection was defined by the presence of anti-HCV. 'Data were analyzed statistically by the t-test for means and chi-square/Fisher's exact test for frequencies. dFourteen and 3 subjects were infected with HCV genotype 1 and HCV genotype 2, respectively. ns, Not significant.

\begin{tabular}{|c|c|c|c|c|c|c|c|c|c|}
\hline \multirow[t]{2}{*}{ Socio-demographic characteristics } & \multicolumn{3}{|c|}{$\mathrm{HBV}(\mathrm{N}=102)$} & \multicolumn{3}{|c|}{$\mathrm{HCV}(\mathrm{N}=102)$} & \multicolumn{3}{|c|}{ Genotype HCV (N = 39) } \\
\hline & Positive & Negative & $P$ value ${ }^{c}$ & Positive & Negative & $P$ value & $\mathrm{HCV} 3$ & $\begin{array}{l}\text { Other } \\
\text { genotypes }^{d}\end{array}$ & P value ${ }^{C}$ \\
\hline Gender - male (\%) & 83.3 & 88.4 & ns & 90.1 & 74.2 & $<0.04$ & 92.9 & 92.0 & ns \\
\hline Age (mean in years) & 34.7 & 32.3 & ns & 34.7 & 31.3 & $<0.04$ & 35.8 & 33.6 & ns \\
\hline Prison history (\%) & 68.6 & 31.4 & $<0.04$ & 82.4 & 17.6 & $<0.006$ & 71.4 & 48.0 & ns \\
\hline Age of first injection (mean in years) & 19.9 & 19.0 & ns & 18.8 & 21.4 & $<0.03$ & 17.0 & 20.6 & $<0.03$ \\
\hline Duration of iv drug use (mean in years) & 14.4 & 13.1 & ns & 15.5 & 9.9 & $<0.005$ & 18.8 & 13.0 & $<0.05$ \\
\hline $\begin{array}{l}\text { Frequency of injection in the last } \\
6 \text { months }(\%)(\geq \text { once a week) }\end{array}$ & 62.7 & 57.9 & ns & 64.7 & 50.0 & ns & 85.7 & 52.0 & $<0.04$ \\
\hline Needle sharing in the last 6 months (\%) & 61.0 & 69.2 & ns & 73.5 & 41.4 & $<0.003$ & 64.3 & 80.0 & ns \\
\hline $\begin{array}{l}\text { Male homosexual intercourse in the } \\
\text { last } 5 \text { years }(\%)\end{array}$ & 84.3 & 64.9 & $<0.04$ & 74.6 & 83.3 & ns & 84.6 & 60.9 & ns \\
\hline
\end{tabular}


$69.6 \%$ of the subjects, in agreement with other studies carried out among IDUs $(19,20)$. It is noteworthy that the majority of these subjects $(70.6 \%)$ are able to transmit $\mathrm{HCV}$ to other IDUs, since HCV-RNA was found in their sera.

HCV infection was significantly associated, both by univariate and multivariate analyses, with longer duration of $i v$ drug use, in agreement with previously reported data (21). Likewise, a high rate of needle sharing in the last 6 months (64.3\%) was observed, and this variable constituted another risk determinant for $\mathrm{HCV}$ infection, as previously observed (19). In the final multiple logistic regression model only these two associations, among the six associations previously identified by univariate analysis, remained as independent risk factors for $\mathrm{HCV}$ infection. Probably the variables "age" and "age at first injection" are, in fact, confounders for the other variables associated with higher levels of exposure to parenteral risks of transmission.

HBV and HCV infections were both associated with prison history in the univariate analysis ( $\mathrm{P}<0.04$ and $\mathrm{P}<0.006$, respectively), but these associations did not remain in the final multivariate analysis. We should remark that in our sample only $5 \%$ of individuals reported needle-sharing while imprisoned. The international literature also highlights the risks of HIV and HBV transmission due to unprotected sexual intercourse while imprisoned, a fact that should be reassessed in future studies to be carried out in Brazil $(22,23)$.

The observed association between higher levels of HCV infection and male gender $(\mathrm{P}<0.04)$, although not confirmed by multivariate analysis, was mentioned in previous studies, which showed that women eliminate HCV more frequently than men $(24,25)$. No association was found between $\mathrm{HCV}$ infection and sexual risk behavior, confirming previous findings that hepatitis $\mathrm{C}$ among IDUs seems to be a consequence of repeated exposure to contaminated injection equipment (21). The distribution of HCV genotypes found here parallels the patterns observed in non-IDU populations from Brazil, with a higher prevalence of genotype 1 (26). However, the frequency of $\mathrm{HCV}$ genotype 3 among IDUs was relatively high in comparison with other populations (15), as also observed among German IDUs (27). In our investigation, $\mathrm{HCV}$ genotype 3 infection was positively associated with younger age at first injection $(\mathrm{P}<0.03)$, longer duration of $i v$ drug use $(\mathrm{P}<0.05)$ and frequency of injection $(\mathrm{P}<0.04)$. These results suggest that the dissemination of HCV genotype 3 among IDUs could be a consequence of cumulative and repeated parenteral exposure to this genotype.

Infections by HDV were not detected in this study. This profile is remarkable since even in areas of low endemicity for HDV, 17-98\% of HbsAg-positive IDUs present HDV antibodies (9).

In our sample, the most frequently injected drug was cocaine $(92.2 \%)$. This seems to be an important aspect of the Brazilian drug scene, since cocaine injectors are under higher risk for blood-borne pathogen infections when compared with opiate injectors. Cocaine addicts repeatedly inject drugs over short periods of time, in "binges", increasing the chance of viral exposure through the common use of injection equipment (28-30). A significant association between $i v$ cocaine use and risky sex behavior has been pointed out in previous studies (31).

In the Southeast of Brazil, especially in Rio de Janeiro, cocaine is mainly administered by snorting (32), although the use of crack cocaine seems to be increasing (3335). Former studies on the transition from non-injecting to injecting illicit drugs indicate that a period from months to years generally elapses between consuming by noninjecting routes and injecting (36), highlighting the need for preventive programs directed at both injecting and non-injecting 
cocaine users.

IDUs constitute an important source of viral infections and therefore can play an important role in the transmission of viruses to the general population. Hence, a public health intervention with the implementation of comprehensive prevention programs including information, face-to-face education, empowerment strategies, distribution or exchange of clean injecting equipment and distribution of condoms must be encouraged. These measures are especially relevant in developing countries like Brazil, where Public Health programs are underbudgeted and understaffed, and frequently lack expertise and political support to implement these programs (37).

Moreover, hepatitis B vaccination of all IDUs should be mandatory, not only as a direct strategy of prevention of new HBV infections, but also as a way to contact hardto-reach IDUs and engage them in different preventive activities. Current vaccination programs attest that this is a feasible and practical initiative, with a high cost/benefit ratio both in terms of human lives to be saved and financial resources to be spared $(38,39)$.

\section{Acknowledgments}

To R.R. Sabino, L.A. Mercadante, L.D.A. Silva and H. Roeske for technical assistance.

\section{References}

1. Purcell RH (1995). The hepatitis viruses: an overview. In: Nishioka K, Suzuki $\mathrm{H}$, Mishiro S \& Oda T (Editors), Viral Hepatitis and Liver Disease. Springer Verlag, Tokyo, J apan.

2. Grosheide P \& van Damme P (1996). Prevention and control of hepatitis $B$ in the community. In: Hallauer J, Kane $M$, McCoy E, Meleus A \& Moure C (Editors), Communicable Diseases Series, 1. World Health Organization, Geneva.

3. Hadziyannis SJ (1997). Hepatitis delta: an overview. In: Rizzetto $M$, Purcell $\mathrm{RH}$, Gerin J L \& Verme G (Editors), Viral Hepatitis and Liver Disease. Edizioni Minerva Medica, Rome, Italy, 283-289.

4. Gish RG \& Lau J YN (1997). Hepatitis C virus: eight years old. Viral Hepatitis Reviews, 1: 17-37.

5. Moyer LA \& Mast EE (1994). Hepatitis B: virology, epidemiology, disease and prevention and an overview of viral hepatitis. American J ournal of Preventive Medicine, 10: 45-55.

6. Purcell RH \& Gerin J L (1996). Hepatitis delta virus. In: Fields BN, Knipe DM, Howley PM, Chamock RM, Melnick J L, Monath TP, Roizman B \& Strauss SE (Editors), Fields Virology. Lippincott-Raven Publishers, Philadelphia, Vol. 2. 28192829.

7. Colombo M (1997). Hepatocellular carcinoma: an overview. In: Rizzetto M, Purcell RH, Gerin J L \& Verme G (Editors), Viral Hepatitis and Liver Disease. Edizioni Minerva Medica, Rome, Italy, 479-483.
8. Telles PR, Bastos FI, Guydish J, Inciardi J A, Surratt HL, Pearl M \& Hearst N (1997). Risk behavior and HIV seroprevalence among injecting drug users in Rio de J aneiro, Brazil. AIDS, 11 (Suppl 1): S35S42.

9. Dan M, Rock M, Lilos P \& Shany S (1993). Seroepidemiology of hepatitis $B$ and hepatitis $D$ virus infection among intravenous drug addicts in Israel. International J ournal of Epidemiology, 22: 140-143.

10. Ebeling $F$ (1994). Importance of hepatitis $C$ virus infection in Europe and North America. In: Reesink HW (Editor), Hepatitis $C$ Virus. Current Studies in Hematology and Blood Transfusion. Karger, Amsterdam, Holland.

11. WHO International Collaborative Group (1994). Multicity Study on Drug Injecting and Risk of HIV Infection. World Health Organization, Geneva.

12. Lopes CS, Rodrigues LS \& Sichieri R (1996). The lack of selection bias in a snowball sampled case control study on drug abuse. International J ournal of Epidemiology, 25: 1267-1270.

13. Driesel G, Wirth $D$, Stark $K$, Baumgarten R, Sucker U \& Schreier E (1994). Hepatitis $C$ virus (HCV) genotype distribution in German isolates: studies on the sequence variability in the E2 and NS5 region. Archives of Virology, 139: 379-388.

14. Simmonds $P$, Holmes EC, Cha TA, Chan SW, McOmish F, Irvine B, Bell E, Yap PL, Kolberg J \& Urdea MS (1993). Classification of hepatitis $C$ virus into six major genotypes and a series of subtypes by phylogenetic analysis of NS-5 region. J ournal of General Virology, 74: 23912399.

15. Oliveira MLA, Bastos FI, Sabino RR, Paetzold U, Schreier E, Pauli G \& Yoshida CFT (1999). Distribution of HCV genotypes among different exposure categories in Brazil. Brazilian J ournal of Medical and Biological Research, 32: 279-282.

16. Koester S, Booth RE \& Zhang Y (1996). The prevalence of additional injection-related IV-risk behaviors among injection drug users. J ournal of Acquired Immune Deficiency Syndromes and Human Retrovirology, 12: 202-207.

17. Vanderborght BOM, Reis AMM, Rouzeré CD, Salgado da Silva R, Yoshida CFT, Franco LGP, Maertens G, van Heuverswinjn H \& Pereira J M (1993). Prevalence of anti-hepatitis $C$ virus in the blood donor population of Rio de $\mathrm{J}$ aneiro. Vox Sanguinis, 65: 122-125.

18. Carvalho HB, Mesquita F, Massad E, Bueno TC, Lopes GT, Ruiz MA \& Burattini MN (1995). HIV and infections of similar transmission patterns in a drug injectors community of Santos, Brazil. J ournal of Acquired Immune Deficiency Syndromes and Human Retrovirology, 12: 84-92.

19. Stark K, Schreier E, Mueller R, Wirth D \& Bienzle U (1995). Prevalence and determinants of anti-HCV seropositivity and HCV genotype among intravenous drug users in Berlin. Scandinavian J ournal of Infectious Diseases, 27: 331-337. 
20. Stroffolini $T$, Fiume $A$, Fatale $G$, Regni $F$, Ciccozzi M, Marzolini A \& Mele A (1997). Hepatitis $C$ virus genotypes among intravenous drug users in Italy. Hepatology Research, 9: 20-27.

21. Tibbs CJ (1995). Methods of transmission of hepatitis C. J ournal of Viral Hepatitis, 2: 113-119.

22. Mueller R, Stark K \& GuggenmoosHolzmann I (1995). Imprisonment: a risk factor for HIV infection counteracting education and prevention programmes for intravenous drug users. AIDS, 9: 183-190.

23. Hull HF, Lyons LH, Mann J M, Hadler SC, Steece R \& Skeels MR (1985). Incidence of hepatitis $B$ in the penitentiary of New Mexico. American J ournal of Public Health, 80: 1129-1131.

24. Yamakawa Y, Sata M, Suzuki H, Noguchi S \& Tanikawa K (1996). Higher elimination rate of hepatitis $C$ virus among women. J ournal of Viral Hepatitis, 3: 317-321.

25. Love A, Sigurdsson J R, Stanzeit B, Briem H, Rikardsdottir H \& Widell A (1996). Characteristics of hepatitis $C$ virus among intravenous drug users in Iceland. American Medical J ournal, 143: 631-636.

26. Martins RMB, Vanderborght BOM \& Yoshida CFT (1998). Hepatitis C virus genotypes among blood donors from different regions of Brazil. Memórias do Instituto Oswaldo Cruz, 93: 299-300.

27. Schreier E, Roggendorf M, Driesel G,
Hoehne M \& Viazov S (1996). Genotypes of hepatitis $C$ virus isolates from different parts of the world. Archives of Virology, 11 (Suppl): 185-193.

28. De J arlais DC, Friedman SR, Choopanya K, Vanichseni S \& Ward TP (1992). International epidemiology of HIV and AIDS among injecting drug users. AIDS, 6: 1053-1068.

29. Levine OS, Vlahov D \& Nelson KE (1994). Epidemiology of hepatitis B virus infections among injecting drug users: seroprevalence, risk factors and viral interactions. Epidemiological Reviews, 16: 418436.

30. Watters J K, Estilo MJ , Clark GL \& Lorvick J (1994). Syringe and needle-exchange as HIV/AIDS risk behavior. J ournal of the American Medical Association, 271: 115120.

31. Camacho LM, Brown BS \& Simpson DD (1996). Psychological dysfunction and HIVIAIDS risk behavior. J ournal of Acquired Immune Deficiency Syndromes and Human Retrovirology, 11: 198-202.

32. Barcellos C \& Bastos FI (1996). Redes sociais e difusão de AIDS no Brasil. Boletin de la Oficina Sanitaria Panamericana, 121: 11-24.

33. Nappo AS, Galduroz SC \& Noto AR (1996). Crack use in São Paulo. Substance Use and Misuse, 31: 565-579.

34. Dunn J, Laranjeira RR, da Silveira DX,
Formigoni ML \& Ferri CP (1996). Crack cocaine: an increase in use among patients attending clinics in São Paulo: 19901993. Substance Use and Misuse, 31: 519-527.

35. Szwarcwald CL, Bastos FI, Gravato N Lacerda R, Chequer PN \& Castilho EA (1998). The relationship of illicit drug consume to HIV-infection among commercial sex workers (CSWs) in the city of Santos, São Paulo, Brazil. International J ournal of Drug Policy, 9: 427-436.

36. De J arlais DC, Casriel C, Friedman SR \& Rosemblum A (1992). AIDS and the transition to illicit drug injection: results of a randomized trial prevention program. British J ournal of Addiction, 87: 493-499.

37. De J arlais DC, Stimson GV, Hagan $\mathrm{H}_{\text {, }}$ Perlman D, Choopanya K, Bastos FI \& Friedman SR (1996). Emerging infectious diseases and the injection of illicit psychoactive drugs. Current Issues in Public Health, 2: 130-137.

38. Mezzelani P, Venturini L \& Tumina G (1991) High compliance with a HBV vaccination program among intravenous drug users. J oumal of Infectious Diseases, 163: 923.

39. Kerleau M, Flori YA, Nalpas B, Lanoe J L, Berthelot P \& Fardeau-Gautier M (1995). Cost benefit analysis of vaccinal prevention of hepatitis B policy. Revue d'Epidemiologie et de Sante Publique, 43: 48-60. 